А.Л.Черняев ${ }^{1}$ М.Ю.Шахина ${ }^{2}$

\title{
Патология легкого при пожарах и отравлениях угарным газом
}

\author{
1 - ФГУ " НИИ пульмонологии" ФМБА России: 105077, Москва, ул. 11-я Парковая, 32, к. 2; \\ 2 - 11-е танатологическое отделение Бюро СМЭ ДЗ г. Москвы: 105077, Москва, ул. 11-я Парковая, 32, к. 6
}

\section{A.L.Chernyaev, M.Yu.Shakhina \\ Lung pathology in fire and carbon monoxide poisoning}

\begin{abstract}
Summary
Pathological examination of the lungs was performed in 98 patients died in fire and 25 patients died in enclosed areas (garages); chemico-legal researches of alcohol blood concentration and carboxyhemoglobin blood concentration were also performed. Patients with alcohol inebriation of various severities or with high blood concentration of carboxyhemoglobin died most frequently. A correlation was found between alcohol blood concentration and carboxyhemoglobin blood concentration. The exudative phase of diffuse alveolar damage was a typical pathologic feature in patients died in fire or in enclosed areas. Soot particles were seen in mucous membrane and alveoli of those died in fire. We suppose that the cause of the death in such cases was carbon monoxide poisoning and airways plugging with the soot.

Key words: fire, carbon monoxide poisoning, lung pathology.
\end{abstract}

\section{Резюме}

Проведено патологоанатомическое исследование легких 98 погибших на пожарах и 25 погибших в закрытых помещениях (гаражах) с судебно-химическим определением алкоголя, концентрации карбоксигемоглобина в крови. Показано, что чаще всего погибали лица, находившиеся в состоянии алкогольного опьянения разной степени тяжести, при высокой концентрации карбоксигемоглобина в крови. Между концентрацией алкоголя в крови и концентрацией карбоксигемоглобина существует корреляционная зависимость. Для патологической анатомии легких у погибших на пожаре и в закрытых помешениях характерно наличие экссудативной фазы диффузного альвеолярного повреждения. У погибших во время пожара обнаружено наличие копоти в слизистой оболочке дыхательных путей и альвеолах. По-нашему мнению, смерть наступала от отравления угарным газом и закрытия дыхательных путей копотью.

Ключевые слова: пожар, отравление угарным газом, патологическая анатомия легких.

В последние несколько лет число пострадавших на пожарах и умерших в закрытых помещениях при отравлении угарным газом возрастает. За период с 2002 по 2006 гг. в России число погибших составляет 13,3 человека на 100 пожаров, в США за этот же период 1,2 человека на 100 пожаров [1]. По данным МЧС России, в 2008 г. в стране произошло 200386 пожаров, в результате которых погибли 15165 человек, в т. ч. 584 ребенка [2]. В США за тот же период число пожаров составило 1451 000, в которых погибли 3320 человек [3]. Следовательно, в США по сравнению с Россией произошло в 7 раз больше пожаров, но погибло в 5 раз меньше людей. По статистике, от ожогов на пожаре погибает лишь $18 \%$ пострадавших, в то время как от отравления комплексом токсических газов - $82 \%$ [4]. Считается, что в значительной степени смерть наступает от "задушения в атмосфере негодных для дыхания газов" [5]. При этом источником "горючей нагрузки" чаще всего являются предметы интерьера, выделяющие при горении синильную кислоту, нитрил акриловой кислоты, акролеин, окись углерода (CO), цианистый водород [6, 7]. В составе газов обнаруживаются вещества с различной биологической активностью, в т. ч. чрезвычайно токсичные. Действие таких смесей усугубляется воздействием высоких температур, задымленностью по- мещений и снижением концентрации кислорода [7]. Смерть при пожарах может наступать в разные сроки. Было показано, что концентрация СО в ткани легких в 1,5 раза выше при асфиксии угарным газом, чем при непосредственной гибели в пламени пожаpa [8]. Непосредственной причиной быстрой смерти на месте происшествия (в очаге пожара) считается отравление $\mathrm{CO}$, ингаляция сажи с аспирацией сгорающих материалов, гипоксия, ожоговый шок, дыхательная недостаточность $[9,10]$. Считается, что при отравлении СО происходит нарушение углеводного обмена с развитием гипергликемии [11].

С другой стороны, при действии СО в закрытых помещениях (гаражи, дома с печным отоплением, шахты) легкие также подвергаются выраженным изменениям, что определяет острую дыхательную недостаточность.

В тоже время, описания патологической анатомии легких погибших при пожарах и при отравлениях СО носят разрозненный, не систематизированный характер [12-14], хотя острое поражение легких у выживших в таких условиях определяет дальнейшую тактику реанимационных мероприятий.

Целью исследования было описание патологической анатомии легких у погибших на пожарах и при отравлении угарным газом в закрытых помещениях. 


\section{Материалы и методы}

В основу работы положены данные патологоанатомического анализа острых отравлений угарным газом и "удушения" в очагах пожаров на валовом секционном материале 11-го танатологического отделения Бюро судебно-медицинской экспертизы Департамента здравоохранения г. Москвы за период с 1995 по 2009 гг. - 42789 аутопсий.

У всех погибших определяли в крови концентрацию карбоксигемоглобина методом газовой хроматографии [7], алкоголя в крови и моче спектрофотометрически, а также содержание глюкозы в крови [11].

Макроскопическое и гистологическое исследование было проведено на аутопсийном материале легких 98 погибших во время пожара (74 мужчины и 24 женшины) и 25 погибших в гаражах, в автомашинах при отравлении угарным газом (20 мужчин и 5 женщин). Возраст погибших составил от 21 до 61 года (средний возраст $-42 \pm 4$ года).

Для гистологического исследования брали кусочки ткани легкого из верхних и нижних отделов, кусочки трахеи и крупных хрящевых бронхов, которые фиксировали в 10\%-ном забуференном по Лилли формалине, проводили материал по общепринятой методике. Кусочки ткани заливали в парафин, приготавливали срезы толщиной 4-6 мкм, которые окрашивали гематоксилином и эозином. Готовые препараты просматривали в световом микроскопе Laborlux $S$ (Leica, Германия).

\section{Результаты и обсуждение}

Из 42789 погибших 5124 человека умерли от отравления $(11,9 \%)$, из них - от отравления СО - 556 человек, что составило $1,3 \%$. На долю погибших при пожарах приходится 443 наблюдения (79,7 \%), погибших в гаражах и машинах - 113 (20,3\%).

В крови 85,5\% мужчин и 67,5 \% женщин обнаружен алкоголь. Среди погибших на пожарах у 8,1\% выявлена легкая степень опьянения (концентрация этилового спирта в крови до 1,5\%о), у 14,6\% - средняя степень (1,6-2,5\%о), у 61,8 \% - тяжелая степень опьянения (> 2,5\%о). В 19 наблюдениях $(15,4 \%)$ алкоголь в крови и моче не был обнаружен. При смерти в гаражах и машинах 20 человек (80\%) находились в состоянии алкогольного опьянения, из них легкая степень опьянения обнаружена у $60 \%$, средняя степень - у $25 \%$, тяжелая - у $15 \%$.

Концентрация карбоксигемоглобина в условиях пожаров колебалась от 59,2 \% (при отсутствии алкоголя в крови) до 69,3\% (при средней степени опьянения). У погибших в закрытых машинах и гаражах концентрация карбоксигемоглобина колебалась от $70,5 \%$ (при отсутствии алкоголя) до $81 \%$ (при тяжелой степени опьянении). В среднем концентрация карбоксигемоглобина у всех погибших на пожарах была достоверно ниже и составила $61,4 \pm 1,8 \%$, в гаражах и машинах $-74,8 \pm 3,1 \%(p<0,05)$. Содержание карбоксигемоглобина в крови при ожогах I-III степени до 30 \% площади тела (61 человек) было до-

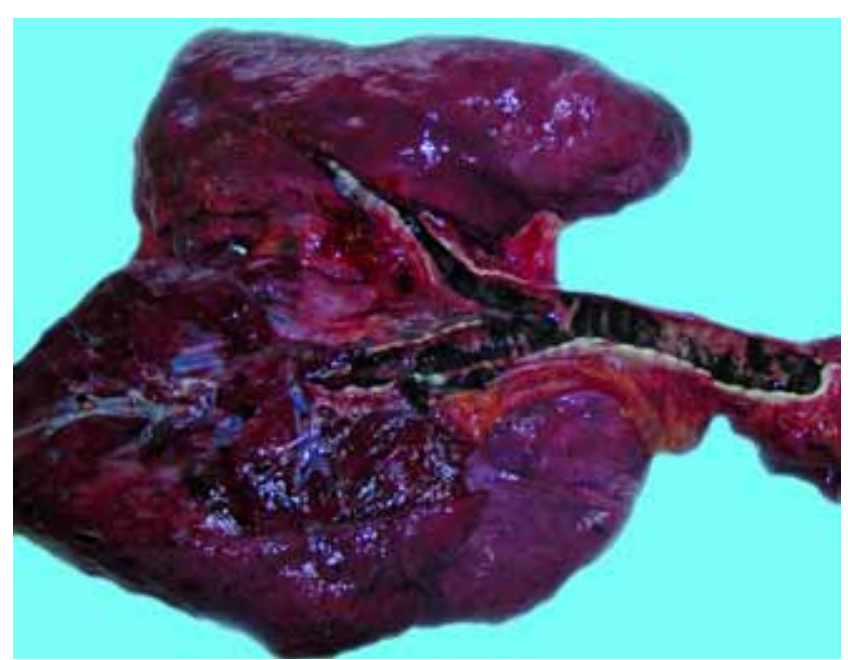

Рис. 1. Макропрепарат легких погибшего на пожаре: большое количество слизи с примесью копоти в просвете трахеи и бронхов

стоверно выше, чем при обугливании кожных покровов более $50 \%$ площади тела (37 человек) и составило соответственно $67 \pm 1,2 \%$ и $56 \pm 1,3 \%(p<0,05)$.

У $23 \%$ из 123 погибших от действия СО имели место признаки гипергликемии (повышение уровня глюкозы > 5,8 ммоль / л, в среднем составившее 11,7 \pm 1,8 ммоль / л), в 63,9 \% наблюдалась гипогликемия уровень глюкозы крови составил 2,9 \pm 1,3 ммоль / л, в 13,1\% случаев уровень глюкозы составил 4,2 \pm 1,5 ммоль / л.

При макроскопическом исследовании легких у погибших на пожаре в просвете трахеи и крупных бронхов обнаружено большое количество густого секрета коричневого цвета, с мозаичным отложением копоти коричнево-черного цвета, слизистая их была серовато-коричневого цвета (рис. 1), легкие занимали всю грудную полость, перекрывая часть области сердца. На поверхности легкие были серокрасные, на разрезе - красные с участками кровоизлияний в различных отделах легких (как в толще легочной ткани, так и под плеврой), с поверхности разрезов стекало скудное или значительное коли-

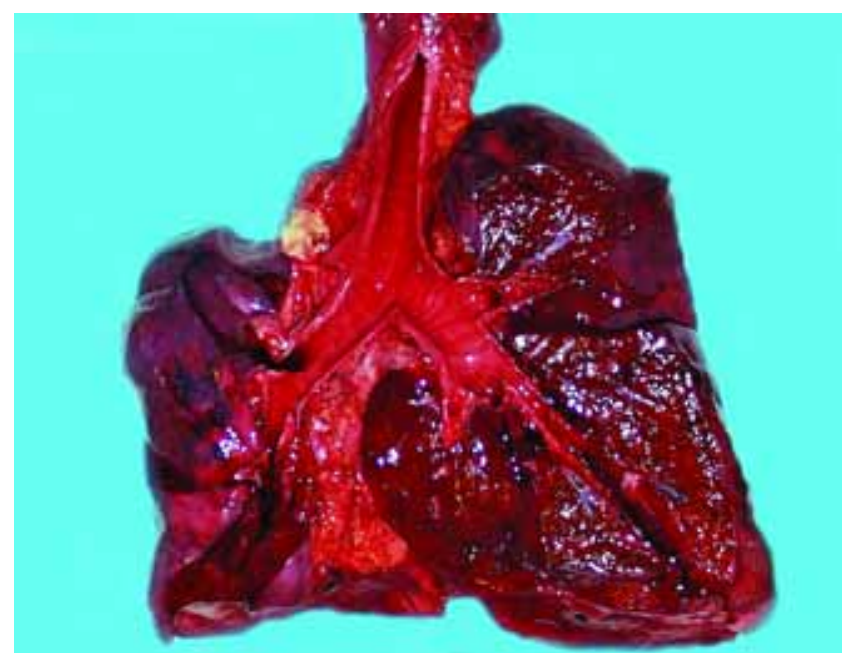

Рис. 2. Макропрепарат легких погибшего от отравления угарным газом в закрытом помешении: ярко-розовая окраска слизистой оболочки дыхательных путей 
чество пенистой жидкости, т. е. степень отека была выражена по-разному. В сегментарных и более мелких бесхрящевых бронхах выявлено умеренное количество буроватой слизи. Лимфатические узлы бифуркации трахеи, ворот легких и паратрахеальные эластичные, размером от 1 до 2,5 см, черного или фиолетового цвета. Обнаружены кровоизлияния под висцеральной и париетальной плеврой, в брюшине, слизистой оболочке желудка и кишечника, что свидетельствует о быстром наступлении смерти.

У погибших в машинах и гаражах просветы трахеи и бронхов были пустые, слизистая оболочка ярко-розового или ярко-красного цвета, такого же цвета - слизистая оболочка всех калибров бронхов (рис. 2). Легкие были, как правило, вздуты, красного или красно-розового цвета с умеренно выраженным отеком.

При гистологическом исследовании у погибших на пожаре были выявлены следующие изменения: наличие частичек копоти в слизистой оболочке трахеи (рис. 3) и бронхов (рис. 4) в сочетании с детритом, содержащим умеренное число полиморфно-

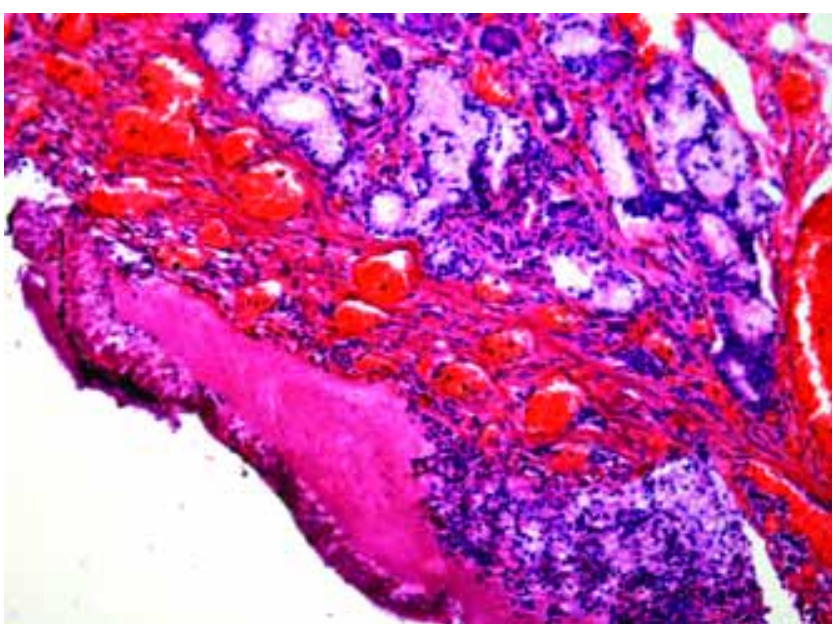

Рис. 3. Десквамация эпителия трахеи, слизь с полоской копоти на поверхности, лимфоидная инфильтрация, полнокровие сосудов собственной пластинки слизистой оболочки, переполнение секретом желез подслизистого слоя. Окраска гематоксилином и эозином; $\times 100$

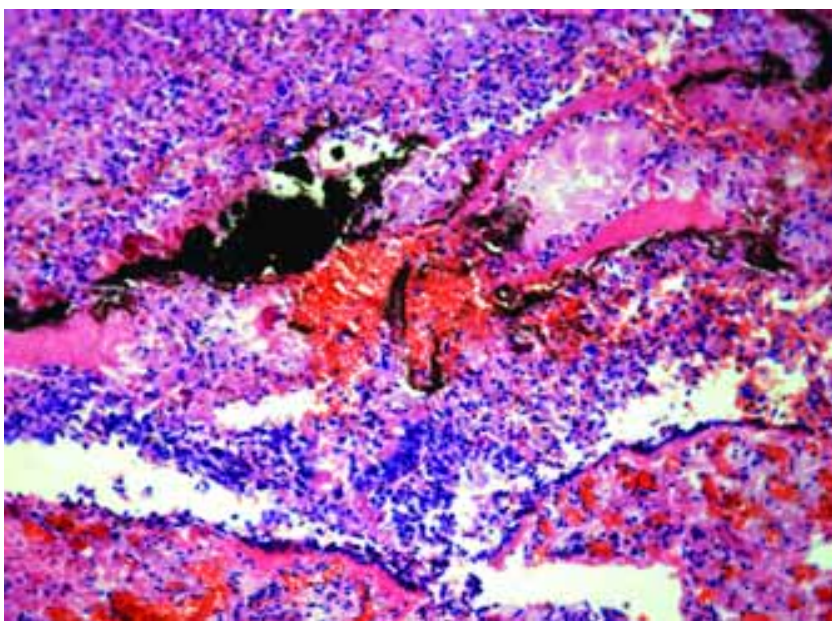

Рис. 4. Десквамация эпителия, слизь, эритроциты и частицы копоти в просвете бронха. Окраска гематоксилином и эозином; $\times 100$

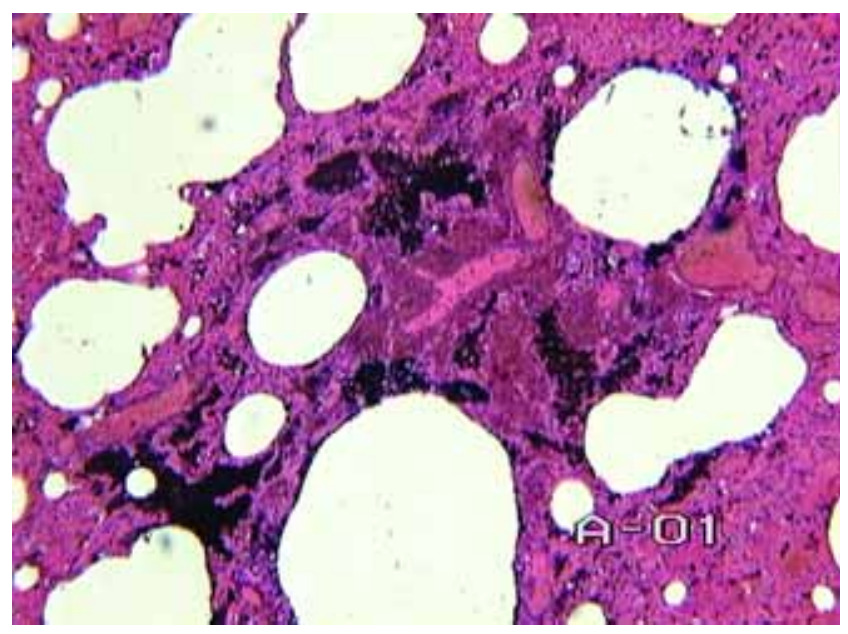

Рис. 5. Острое вздутие легких, полнокровие сосудов, отек со скоплением копоти в просветах альвеол. Окраска гематоксилином и эозином; $\times 40$

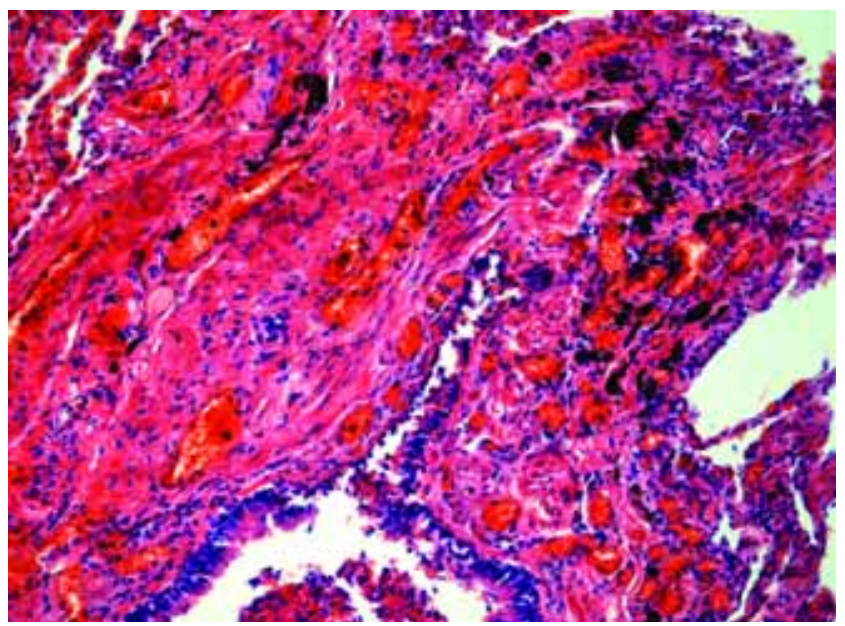

Рис. 6. Периваскулярное отложение копоти в подслизистом слое стенки бронха. Окраска гематоксилином и эозином; $\times 100$

ядерных лейкоцитов в 74 наблюдениях (73,5 \%), бурые частицы копоти черно-коричневого цвета, расположенные внутриальвеолярно, обнаружены у 21 погибшего $(21,4 \%)$, часть из которых плотно прилегали к стенкам альвеол (рис. 5) или выстилали стенки респираторных бронхиол, встречались отложения черного пигмента периваскулярно (рис. 6), бокаловидноклеточная гиперплазия с соотношением бокаловидных клеток к реснитчатым 1 : 1 наблюдалась у 17 погибших (17,3 \%), гиперплазия желез подслизистого слоя обнаружена в 30 наблюдениях $(30,6 \%)$, десквамация эпителия трахеи и бронхов в $31(31,6 \%)$, резко выраженное полнокровие стенок трахеи, бронхов, капилляров межальвеолярных перегородок в $100 \%$ наблюдений, внутриальвеолярный и интерстициальный отек - в 61 (64,3\%), острое вздутие легких - в $53(54,1 \%)$, интраальвеолярные кровоизлияния - в 31 (30,6\%), в 2 наблюдениях (2\%) обнаружены единичные гиалиновые мембраны по контуру небольшого числа альвеол.

У умерших в гаражах и машинах десквамация эпителия была менее выраженной и встречалась у 10 погибших (40\%), отсутствовали полоски копоти на эпителии, наблюдалось выраженное полнокровие 
сосудов собственной пластинки слизистой оболочки трахеи и крупных бронхов, умеренно выраженная гиперплазия и гипертрофия желез подслизистого слоя. В респираторной ткани наблюдался разной степени выраженности интерстициальный и внутриальвеолярный отек. У погибших в гаражах встречались группы альвеол с резко расширенными пустыми капиллярами межальвеолярных перегородок. Терминальные и респираторные бронхиолы, альвеолярные ходы, как правило, не были расширены. Встречались очаговые внутриальвеолярные кровоизлияния - в 8 наблюдениях (32\%).

При рассмотрении причины смерти в условиях пожара следует говорить о нескольких факторах, являющихся непосредственной причиной смерти. Это, прежде всего, остро возникающее удушье, связанное с поступлением большого количества продуктов сгорания, прежде всего сажи, возникновением ожогового шока, но самое главное - это отравление угарным газом [5, 13]. Морфологическими признаками "острой" смерти во время пожара являются множественные кровоизлияния во внутренних органах, включая легкие, и нарушение микроциркуляции в органах и тканях. Признаками острого альвеолярного повреждения является наличие интерстициального и внутриальвеолярного отека, очаговые внутриальвеолярные кровоизлияния. При световой и электронной трансмиссионной микроскопии у погибших на пожаре при аутопсии в трахее были обнаружены частицы копоти, выраженное полнокровие сосудов дыхательных путей, внутриклеточный отек альвеолоцитов I типа, появление пузырьков и везикул в альвеолоцитах I типа и эндотелиоцитах, накопление частиц копоти в альвеолярных макрофагах [15]. Гиалиновые мембраны, как правило, не успевают появиться, хотя в 2 наблюдениях они имели место, что, скорее всего, свидетельствует о длительном нахождении погибших до момента смерти в атмосфере смешанных токсических газов. Описанные нами патологоанатомические изменения в ткани легких и дыхательных путях практически полностью согласуются с данными L.A. de Paiva et al. [16]. В этом исследовании с помощью полуколичественного метода с использованием математической модели было выявлено, что основными морфологическими признаками при непосредственном действии пламени являются расширение бронхиол и острое вздутие нижележащих отделов в сочетании с внутриальвеолярным кровоизлиянием. Удушье, вызванное действием продуктов горения и СО, приводит к коллапсу альвеол, закупорке просветов бронхиол детритом с частичками копоти, выраженному интерстициальному и внутриальвеолярному отеку.

Каково же значение копоти на слизистой оболочке дыхательных путей и в просветах альвеол? Попадание сажи в дыхательные пути ведет к реакции дыхательной системы в виде увеличения объема слизи за счет бокаловидно-клеточной гиперплазии и гиперплазии подслизистых желез. Инородная пыль приводит к десквамации эпителия трахеи и крупных бронхов и создает почву для массивной аспирации, что в дальнейшем, если человек выживает на пожаpe, приводит к развитию пневмонии в течение первых 3 сут. [13]. Такое выраженное повреждение органов дыхания во время пожара в отдаленные сроки может приводить к развитию хронического бронхита и бронхиолита с выраженным кашлевым симптомом, к очаговым интерстициальным изменениям по типу альвеолита, как это было описано после террористического акта в Нью-Йорке [17].

Как глубоко может проникать сажа (копоть) в дыхательные пути? Скорее всего, это зависит от длительности нахождения человека в зоне пожара и глубине вдыхания загазованной атмосферы. В начале прошлого века поднимался вопрос, почему при одном пожаре у взрослых наблюдали отложения копоти в просветах трахеи, бронхов и альвеол, в то время как у погибших в том же пожаре детей до 3 лет копоти в просветах перечисленных выше структур не наблюдалось [12]. Автор не дает объяснения этому явлению. С нашей точки зрения, у маленьких детей смерть наступала раньше, чем у взрослых за счет более быстрого отравления окисью углерода. Считается, что обнаружить копоть в просветах дыхательных путей у погибших и выживших во время пожара можно только тогда, когда человек находился в этих условиях не менее 30-45 мин [18]. При смерти людей в гаражах и машинах изменения в легких при отравлении окисью углерода носят вторичный характер и связаны, прежде всего, с угнетением нервной системы [11].

\section{Заключение}

Концентрация карбоксигемоглобина в крови умерших достоверно выше у погибших в закрытых помещениях, чем на пожарах. В 63,9 \% при отравлении угарным газом имеет место гипергликемия. Содержание карбоксигемоглобина при ожогах > 50 \% площади тела достоверно ниже, чем при ожогах $<30 \%$ площади тела.

У погибших на пожаре отмечаются гистологические признаки диффузного альвеолярного повреждения, десквамативный бронхит, пигментация эпителия хрящевых бронхов и наличие пигментированных макрофагов в альвеолах и респираторных бронхиолах, признаки острого вздутия легких. При гибели в закрытых помещениях (гаражи и автомашины) имеют место начальные проявления диффузного альвеолярного повреждения. Гистологических признаков бронхоспазма в нашем материале обнаружить не удалось.

\section{Литература}

1. Пожары в мире. http://www.emer.kz/news/detail.php?ID

2. Статистика пожаров в России в 2008 году. МЧС. http://www.mchs.gov.ru/stats/detail.php

3. Сравнительная статистика пожаров в США и России. http://www.usfa.dhs.gov/statistics national/index.shtm/

4. Яблочкин В.Д. Смерть на пожаре. Химия и жизнь - XXI век 1997; 2: 105-109. 
5. Краттер Ю. Руководство по судебной медицине. Ч. 1: Телесные повреждения. Под ред. Я.Лейбович. М.: Издво Наркомздрава: 116-118.

6. Бабаханян Р.В., Белешников Н.Л., Петров Л.В. Токсичность компонентов газовой среды пожара. В кн.: Первый съезд судебных медиков Казахстана. Тезисы докладов Чимкент; 1989: 105-106.

7. Яблочкин В.Д. Экспертное значение определения летучих продуктов горения неметаллических материалов при исследовании крови погибших на пожаре. Суд.мед. эксперт.; 2000; 6: 30-32.

8. Vreman H.J., Wong R.J., Stevenson D.K. et al. Concentration of carbon monoxide (CO) in postmortem human tissues: effect of environmental CO exposure. J. Forens. Sci. 2006; 51 (5): 1182-1190.

9. Матышев А.А. Судебная медицина. Руководство для врачей. 3-е изд. СПб.: Изд-во "Гиппократ"; 1998. 180-183.

10. Bohnert M., Schmidt U., Werp J.,Simon K.H. Unusual findings in a death caused by a car fire. Arch. Kriminol. 2007; 219 (1-2): 14-22.

11. Пермяков A.B., Витер В.И. Судебно-медицинская гистология. Руководство для врачей. Ижевск; 1998. 174-176.

12. Пузанов А.Н. К вопросу о прижизненных изменениях в почках и легких у погибших в пламени пожаров: Дисс. .... Д-ра мед. наук. СПб; 1909. 74-79.
13. Томилин В.В., Туманов В.П., Осипенкова-Вичтомова Т.К. Диагностика смерти от ожогового шока. Суд.-мед. эксперт. 2001; 5: 3-5.

14. Баринова М.В., Логинов Л.П., Полозов М.А. Морфологические изменения легких при термических ожогах кожи и дыхательных путей. В кн.: Актуальные вопросы патологии человека М.: Изд-во РУДН; 2001. 22-24.

15. Burns T.R., Greenberg S.D., Cartwright J., Jachimczyk J.A. Smoke ingalation: an ultrastructural study of reaction to injury in the human alveolar wall. Environ. Res. 1986; 41 (2): 447-457.

16. de Paiva L.A., Parra E.R., da Rosa D.C. Autopsy-proven determinants of immediate fire death in lungs. Am. J. Forens. Med. Pathol. 2008; 29 (4): 323-329.

17. Prezant D.J., Weiden M., Banauch G.I. et al. Cough and bronchial responsiveness in firefighters at the world trade center site. N. Engl. J. Med. 2002; 347: 806-815.

18. Савостин Г.А., Павлов Ю.В. К оценке степени тяжести телесных повреждений при отравлении угарным газом. В кн.: Актуальные вопросы судебной медицины. М.; 1990. 68-70.

\section{Информация об авторах}

Черняев Андрей Львович - д. м. н., проф., зав. отделом патологии ФГУ «НИИ пульмонологии ФМБА России»; тел.: (495) 465-53-84; e-mail: samary@mail.ru

Шахина Марина Юрьевна - к. м. Н., и. о. зав. 11-го танатологического отделения Бюро СМИ дЗ г. Москвы; тел.: (495) 965-74-14; e-mail: shahinamarina@mail.ru 